\title{
Effect of Wood Waste and Sunflower Husk Biochar on Tensile Strength and Porosity of Dystric Cambisol Artificial Aggregates
}

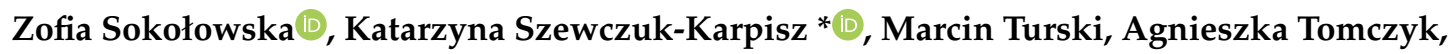 \\ Marta Cybulak (D) and Kamil Skic
}

\author{
Institute of Agrophysics, Polish Academy of Sciences, 20-290 Lublin, Poland; z.sokolowska@ipan.lublin.pl (Z.S.); \\ mturski@ipan.lublin.pl (M.T.); a.tomczyk@ipan.lublin.pl (A.T.); m.cybulak@ipan.lublin.pl (M.C.); \\ kskic@ipan.lublin.pl (K.S.) \\ * Correspondence: k.szewczuk-karpisz@ipan.lublin.pl; Tel.: +744-50-61
}

Received: 17 December 2019; Accepted: 4 February 2020; Published: 6 February 2020

check for updates

\begin{abstract}
This paper focuses on the tensile strength $(Q)$ and porosity of Dystric Cambisol cylinders with and without biochars $(0.1 \%$ or $5 \%$ dose) obtained from wood waste (BC1) and sunflower husks (BC2). The experiments were performed on air-dried and wetted artificial aggregates remolded from unfractionated soil and its selected fractions (1-0.25, 0.25-0.1, 0.1-0.05, and $<0.05 \mathrm{~mm}$ ). The obtained results indicated that the biochar addition reduced the tensile strength of all examined samples, regardless of the type of biomass used in pyrolysis. This effect was more significant with the larger biochar dose of $5 \%$. When cylinders formed from a wetted $1-0.25 \mathrm{~mm}$ fraction with $5 \% \mathrm{BC}$, the $Q$ reduction equaled as much as $0.048 \mathrm{MPa}$. The noted decrease in tensile strength was mainly associated with the formation of macropores in the cylinders (of maximum radii: $4.77 \mu \mathrm{m} \mathrm{BC1}$ and $5.78 \mu \mathrm{m}$ $\mathrm{BC} 2$ ). The highest tensile strength was observed in the air-dried samples formed from the largest silica-rich fraction $(1-0.25 \mathrm{~mm})$ without biochar $(0.078 \mathrm{MPa}$ for the air-dried cylinders and $0.066 \mathrm{MPa}$ for the wetted ones). The higher $Q$ parameter for the air-dried remolded soil aggregates was probably related to the dehydration of soil gels and the thermal transformation of iron and alumina oxides during drying.
\end{abstract}

Keywords: remolded soil aggregates; cylinders; biochar; tensile strength; organic carbon content; porosity

\section{Introduction}

Aggregation is a significant process in soil-it determines a soil's structure, stability, and air-water properties. Aggregation depends on many factors (i.e., soil type, biota, clay mineralogy, cation, and organic matter content) and includes the flocculation and cementation processes of mineral particles by organic compounds [1]. At the first aggregation stage, organic-mineral associations between minerals and organic macromolecules are formed. Usually, cation bridges are created, connecting negatively charged clay minerals [2] and organic macromolecules (e.g., humic substances) [3]. The microaggregates are held together by microorganisms (e.g., fungal hyphae) or the binding agents (i.e., polysaccharides, mucilages) they synthesize [4,5]. Some hydrophobic substances produced by bacteria or fungi (e.g., waxes, lipids) contribute to aggregate stabilization by enhancing water repellency. Soil aggregates with high tensile strength favor gas and water diffusion, root penetration and growth, and increased resistance to erosion [6].

Intensive agriculture and significant environmental pollution contribute to the continuous deterioration of soil conditions. Soil structure is often destroyed, and consequently, the water and air 
properties of soil become unfavorable for plant growth. In order to limit such negative phenomena, various soil additives are often used [7]. Biochar is one of such substances that can prevent negative changes and improve soil condition due to its specific properties. This organic material is obtained in the pyrolysis process from biomass (e.g., wood, leaves, rhizomes, wastes) and is usually characterized by a high specific surface area and numerous surface functional groups, such as carboxylic, phenolic, and lactonic [8]. Generally, biochar has a good sorption ability relative to heavy metals and nutrients [9] as well as high stability in most environments; for example, it demonstrates a high resistance to degradation and chemical oxidation $[10,11]$. Biochar usage in agriculture can bring many benefits: it may increase soil $\mathrm{pH}$ value [12] and organic carbon content [13] as well as reduce $\mathrm{N}_{2} \mathrm{O}$ and $\mathrm{CH}_{4}$ emissions from the soil environment [14]. Biochar is also an important element in cation exchange capacity [15] and may act as a slow-release fertilizer in soils [16]. In some cases, the biochar surface is modified to improve its properties [17-22]. Today, studies on optimizing the production process of biochar are constantly being carried out [23].

Many researchers have investigated the impact biochar has on aggregate formation and stability [24-27]. The published results differ significantly due to the studies' use of complex biochar properties and various soil types. For example, Horel et al. [24] examined the physical properties of silt loam soil after the addition of biochar. They studied natural aggregates and used the following amounts of biochar: $0.5 \%, 2.5 \%$, and $5.0 \%$. The highest aggregate tensile strength was noted for aggregates with a $5.0 \%$ dose of biochar. The examined parameter was two times higher compared to the control. Meanwhile, Ouyang et al. [28] studied silty clay and sandy loam soil aggregation with and without biochar $(2 \%)$ obtained from dairy manure. They examined natural aggregates and stated that the selected carbon-rich material enhanced aggregate formation. The biochar effect was more profound in the sandy loam soil. Šimanský [29] carried out a field experiment in which Haplic Luvisol was simultaneously enriched with biocarbon obtained from paper fiber sludge and grain husks (1:1) and nitrogen fertilizer. Šimanský's study was carried out on natural aggregates and indicated a clear increase in aggregate tensile strength (by 19\%) when $20 \mathrm{t} \mathrm{ha}^{-1}$ of biochar was combined with $80 \mathrm{~kg}$ $\mathrm{ha}^{-1}$ of nitrogen fertilizer. Meanwhile, Khademalrasoul et al. [30] examined the biochar impact on aggregates formed from sandy loam soil under no-till maize and claimed that the aggregates with larger biochar doses had higher tensile strength. Aggregate stability was measured using a wet-sieving method. Moreover, Sun and Lu [27] added various biochars to clayey Vertisol and observed that straw and wastewater-sludge biochars contributed to increases in the mean weight diameter (MWD) and geometric mean diameter (GMD) of the examined aggregates. In other words, Sun and Lu's biochars increased the tensile strength of natural aggregates. Notably, the MWD values were the highest with wastewater sludge biochar (a $28 \%$ increase).

On the other hand, Ajayi and Horn [31] observed that tensile strengths of artificial aggregates of fine sand and sandy loam soils were significantly lower when the amount of woodchip biochar was doubled. Zhou et al. [32] performed experiments on Chinese sandy loam soil and used maize-cob-derived biochar as a soil additive. The experiment was performed on natural aggregates, and stability was tested using the fast-wetting method. The authors stated that maize-cob biochar did not contribute to the formation of macroaggregates of high tensile strength.

In response to the discrepancies in literature reports about the effect of biochar on soil aggregate tensile strength, this paper focuses on the tensile strength of Dystric Cambisol cylinders with and without biochars obtained from wood waste and sunflower husks. The examined soil cylinders were artificially remolded from the unfractionated soil or its selected fractions $(1-0.25 \mathrm{~mm}, 0.25-0.1 \mathrm{~mm}$, $0.1-0.05 \mathrm{~mm}$, and below $0.05 \mathrm{~mm})$ in the laboratory. Two biochar doses $(0.1 \%$ and $5 \%)$ and different sample moistures (air-dried and wetted samples) were under study. The presented results are innovative and of great importance. The model tests, carried out under strictly defined conditions, allow for an accurate explanation of the interaction between the biochar and the soil. These studies also serve as important complements to the field experiments. The authors conducted measurements on Dystric Cambisol, which required remediation due to the low content of organic carbon and acidic 
reaction. Moreover, the selected soil was examined after fractionation to check whether biochar affected the porosity and tensile strength of selected fractions in the same way. The changes in artificial aggregate tensile strength observed with biochar were combined with the pore size distribution in the samples, determined using mercury porosimetry. Such an interpretation of the results is rare in the existing literature. Ultimately, the authors hypothesize that the addition of biochar decreases aggregate tensile strength because large pores form in soil aggregates when biochar is present.

\section{Materials and Methods}

The experiments were performed using a silty soil (Dystric Cambisol) (Rogóżno, Lublin province, Poland, $50^{\circ} 46^{\prime} \mathrm{N}, 23^{\circ} 38^{\prime} \mathrm{E}$ ) taken from a 0-20 cm depth. This soil, due to its low content of organic carbon and acidic reaction, had low fertility and poor suitability for crops. The Dystric Cambisol was air-dried and crushed in a porcelain crucible. Soil fractions of $1-0.25 \mathrm{~mm}, 0.25-0.1 \mathrm{~mm}, 0.1-0.05 \mathrm{~mm}$, and below $0.05 \mathrm{~mm}$ were obtained using the sieves with the following mesh sizes: $1 \mathrm{~mm}, 0.25 \mathrm{~mm}$, $0.1 \mathrm{~mm}$, and $0.05 \mathrm{~mm}$.

Two types of biochar, obtained by the pyrolysis process at $650{ }^{\circ} \mathrm{C}$, were used in the study. The first one (BC1) was prepared from wood waste by Fluid S.A. (Poland), whereas the second one (BC2) was prepared from sunflower husks by New Technology Trade (Poland). Before the experiments, the biochars were crushed in a porcelain crucible and sieved through $2 \mathrm{~mm}$.

\subsection{Soil and Biochar Physicochemical Characterization}

The soil and biochar samples were investigated using several methods. The specific surface area was established using a water vapor adsorption/desorption isotherm method [33]. The sample $\mathrm{pH}$ value was measured in $\mathrm{H}_{2} \mathrm{O}$ and $1 \mathrm{M} \mathrm{KCl}$ solutions using a pH meter (CX-505, Elmetron, Zabrze, Poland). The soil $\mathrm{pH}$ value was determined in a 1:10 suspension, whereas the biochar $\mathrm{pH}$ value was determined in a 1:5 suspension. The sample density was established by a pycnometer (Ultrapycnometer 1000, Quantachrome, Graz, Austria). The organic carbon content in the soil sample was determined using the Tyurin method [34] and in the biochar sample using the Alten method [35]. The ash content was established based on the weighting of the residue after $5 \mathrm{~h}$ of combustion in a muffle furnace $\left(550{ }^{\circ} \mathrm{C}\right.$, FCF 12 SP, Czylok, Jastrzębie-Zdrój, Poland). Meanwhile, the texture of the samples was assessed using the Casagrande-Prószyński method, that is, based on the changes in soil suspension density during the progressive sedimentation of soil particles at a constant temperature and using a Prószyński hydrometer. Each parameter was measured three times. The measurement error (standard deviation) did not exceed $8.5 \%$. The obtained soil and biochar characteristics are summarized in Table 1.

Table 1. Soil and biochar characteristics.

\begin{tabular}{|c|c|c|c|c|}
\hline \multicolumn{2}{|c|}{ Parameter } & Soil & BC1 & BC2 \\
\hline \multicolumn{2}{|c|}{ Specific surface area $\left[\mathrm{m}^{2} / \mathrm{g}\right]$} & $15.2 \pm 0.7$ & $69.9 \pm 2.2$ & $80.9 \pm 2.1$ \\
\hline \multicolumn{2}{|r|}{$\mathrm{pH}_{\mathrm{H} 20}$} & $6.3 \pm 0.1$ & $8.2 \pm 0.1$ & $9.7 \pm 0.2$ \\
\hline \multicolumn{2}{|r|}{$\mathrm{pH}_{\mathrm{KCl}}$} & $6.1 \pm 0.1$ & $7.6 \pm 0.1$ & $9.2 \pm 0.2$ \\
\hline \multicolumn{2}{|c|}{ Density $\left[\mathrm{g} / \mathrm{cm}^{3}\right]$} & $2.6 \pm 0.1$ & $1.5 \pm 0.1$ & $1.4 \pm 0.1$ \\
\hline \multicolumn{2}{|c|}{ Ash content $[\mathrm{w} \%]$} & $97.0 \pm 1.5$ & $43.7 \pm 1.8$ & $35.4 \pm 1.1$ \\
\hline \multicolumn{2}{|c|}{ Organic carbon content [\%] } & $1.2 \pm 0.1$ & $12.3 \pm 0.2$ & $22.5 \pm 0.2$ \\
\hline \multirow{3}{*}{ Texture [\%] } & Sand $(2-0.05 \mathrm{~mm})$ & $16 \pm 1.2$ & - & - \\
\hline & Silt $(0.05-0.002 \mathrm{~mm})$ & $75 \pm 1.5$ & - & - \\
\hline & Clay $(<0.002 \mathrm{~mm})$ & $9 \pm 0.8$ & - & - \\
\hline
\end{tabular}




\subsection{Aggregate Preparation}

The soil cylinders were remolded using the unfractionated Dystric Cambisol or its selected fractions with or without the addition of selected biochars at $0.1 \%$ or $5 \%$ doses. At the beginning, $10 \mathrm{~g}$ of the air-dried unfractionated soil or its fraction was wetted by $2 \mathrm{~mL}$ of demineralized water. Then, the wetted material was placed in a closed chamber for $48 \mathrm{~h}$. After this time, the aggregates were formed using a special plastic syringe (Figure 1a). The space in the syringe used to form the cylinders was packed maximally (to ensure that no more material could be inserted). A single artificial aggregate had the following dimensions: $\mathrm{d}$ (diameter) $=10 \mathrm{~mm}$, $\mathrm{h}$ (height) $=7 \mathrm{~mm}$ (Figure $1 \mathrm{~b}$ ).

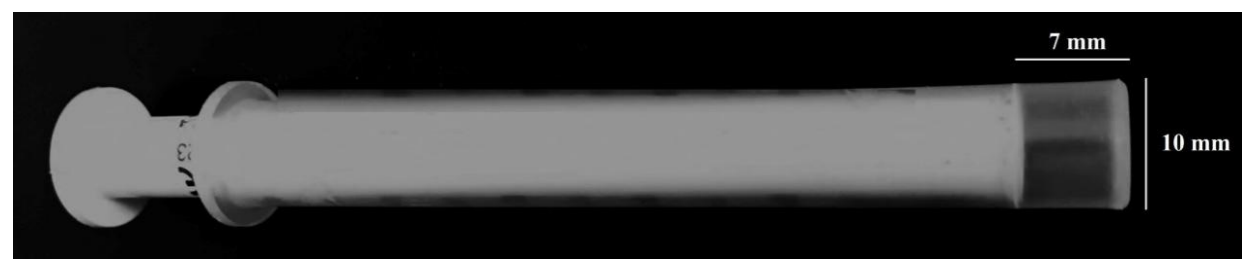

(a)

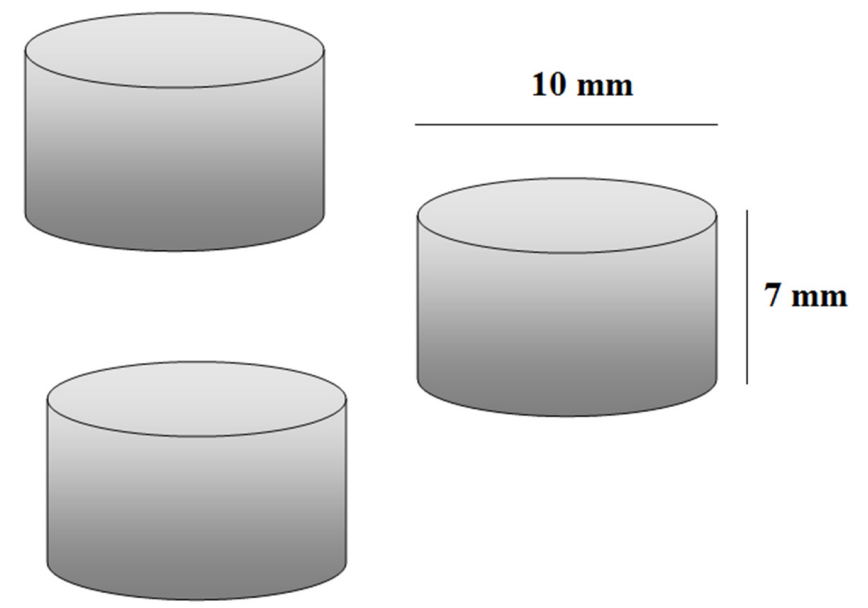

(b)

Figure 1. Photo of the plastic syringe used in cylinder formation (a) and schematic representation of prepared cylinders $(\mathbf{b})$.

\subsection{Porosity Measurement}

Total porosity and pore size distribution (PSD) of the pure biochars, Dystric Cambisol, and prepared cylinders were determined using an autopore IV 9500 (Micrometrics INC, Norcross, GA, USA) mercury porosimeter. Mercury intrusion porosimetry was accepted as a standard method to characterize pores in porous materials by ASTM International (American Society for Testing and Materials) [36]. It provides information on pore size distribution as affected by soil management practices [37], including water-filled pores at field water capacity at the water potential of $-10 \mathrm{kPa}(<15 \mu \mathrm{m})$ [38].

To characterize the biochars and soil used in the experiments, the samples were examined as loose/unpacked materials. To define the impact of biochar on the PSD and total porosity of artificial soil aggregates, the unfractionated Dystric Cambisol or its fractions with or without biochar were studied in the form of cylinders. At the beginning, the examined material was dried at $105^{\circ} \mathrm{C}$ and degassed in a vacuum under a pressure of $6.67 \mathrm{~Pa}$. Then, the mercury was intruded to the samples at a slowly increasing pressure in the range of $0.0035-400 \mathrm{MPa}$, which allows PSD determination in the range of $0.0016-178 \mu \mathrm{m}$. Pore size was calculated using the Washburn equation [39]:

$$
P=\frac{2 \gamma_{H g} \cos \theta}{r}
$$


where $P$ represents the external pressure $(\mathrm{Pa})$ applied in the vacuum chamber, $\gamma_{\mathrm{Hg}}$ represents the surface tension of mercury $\left(0.485 \mathrm{~J} / \mathrm{m}^{2}\right), \theta$ represents the contact angle of mercury $\left(130^{\circ}\right)$, and $r$ represents the pore radius of pore aperture $(\mathrm{m})$ for a cylindrical pore.

The obtained results were presented in two forms: (1) the cumulative pore volume against a logarithmically spaced radii and (2) the differential PSD based on the logarithmic differentiation $\mathrm{dv} / \mathrm{d} \log$. Mean pore radius (2V/A) was obtained assuming that all pores were cylindrical, and thus the pore volume $\left(\mathrm{V}=\pi r^{2} \mathrm{~L}\right)$ was divided by the pore area $(\mathrm{A}=2 \pi r \mathrm{~L})$. Total porosity was calculated from the ratio of the total intruded mercury volume at the highest pressure (400 MPa) to the total sample volume. A single result was the mean of 3 replicates. The measurement error (standard deviation) did not exceed $6.3 \%$.

\subsection{Structural Stability Measurements}

The measurements of cylinder tensile strength $(Q, \mathrm{MPa})$ were carried out using a strength-testing device (Zwick/Roell). This apparatus crushes the cylinders with a specific force. The experiments were performed on dry samples, that is, samples dried at $105^{\circ} \mathrm{C}$ for $2 \mathrm{~h}$ in a laboratory dryer, and wetted ones (formed using the material wetted by distilled water in the ratio of $10 \mathrm{~g} / 2 \mathrm{~mL}$ ). The tensile strength of the examined material was calculated according to the formula [40]:

$$
Q=\frac{2 F}{\pi d h^{\prime}}
$$

where $F$ represents the vertical breaking force $(\mathrm{N}), d$ represents the cylinder diameter $(\mathrm{m})$, and $h$ represents the cylinder height $(\mathrm{m})$.

A single result was the mean of 30 replicates.

\subsection{Statistical Analysis}

Statistical analyses of tensile strength, organic carbon content, and porosimetry results were performed using a standard student's $t$-test $(p=0.05)$. The letters $\mathrm{a}, \mathrm{b}$, and c indicate the significance of differences between the examined samples. When samples are marked with the same letter, there is no significant difference between them.

To compare the impacts of several factors on the tensile strengths of the samples, a statistical analysis—a multivariate ANOVA—of the tensile strength results was also performed using Statistica 12.0 (StatSoft Inc., Tulsa, OK, USA).

\section{Results and Discussion}

\subsection{Physicochemical Properties of Dystric Cambisol and Biochars}

As shown in Tables 1 and 2, the soil and biochars used for the cylinder preparation have different physicochemical properties.

Table 2. Porosity characteristics of the soil and biochars used in cylinder preparation.

\begin{tabular}{ccccc}
\hline & $\begin{array}{c}\text { Total Intrusion } \\
\text { Volume }\left[\mathbf{c m}^{3} / \mathbf{g}\right]\end{array}$ & $\begin{array}{c}\text { Average Pore } \\
\text { Radius }[\boldsymbol{\mu m}]\end{array}$ & $\begin{array}{c}\text { Total Pore Area } \\
{\left[\mathbf{m}^{2} / \mathbf{g}\right]}\end{array}$ & Total Porosity [\%] \\
\hline Soil & $0.38 \pm 0.02$ & $0.55 \pm 0.03$ & $1.38 \pm 0.07$ & $49.18 \pm 1.53$ \\
\hline BC1 & $2.31 \pm 0.14$ & $0.20 \pm 0.01$ & $22.72 \pm 1.41$ & $74.45 \pm 2.54$ \\
\hline BC2 & $2.28 \pm 0.11$ & $0.24 \pm 0.01$ & $19.01 \pm 0.89$ & $75.92 \pm 3.02$ \\
\hline
\end{tabular}

The studies were conducted on Dystric Cambisol with clay, silt, and sand contents equal to 9\%, $75 \%$, and $16 \%$, respectively. This soil was characterized by a low organic carbon content and a slightly acidic reaction. The porosity parameters of Dystric Cambisol were low, that is, its total pore area 
equaled $1.38 \mathrm{~m}^{2} / \mathrm{g}$, whereas total porosity was $49.18 \%$. The cumulative and differential curves of pore volume vs. equivalent pore radius of Dystric Cambisol are presented in Figure 2.
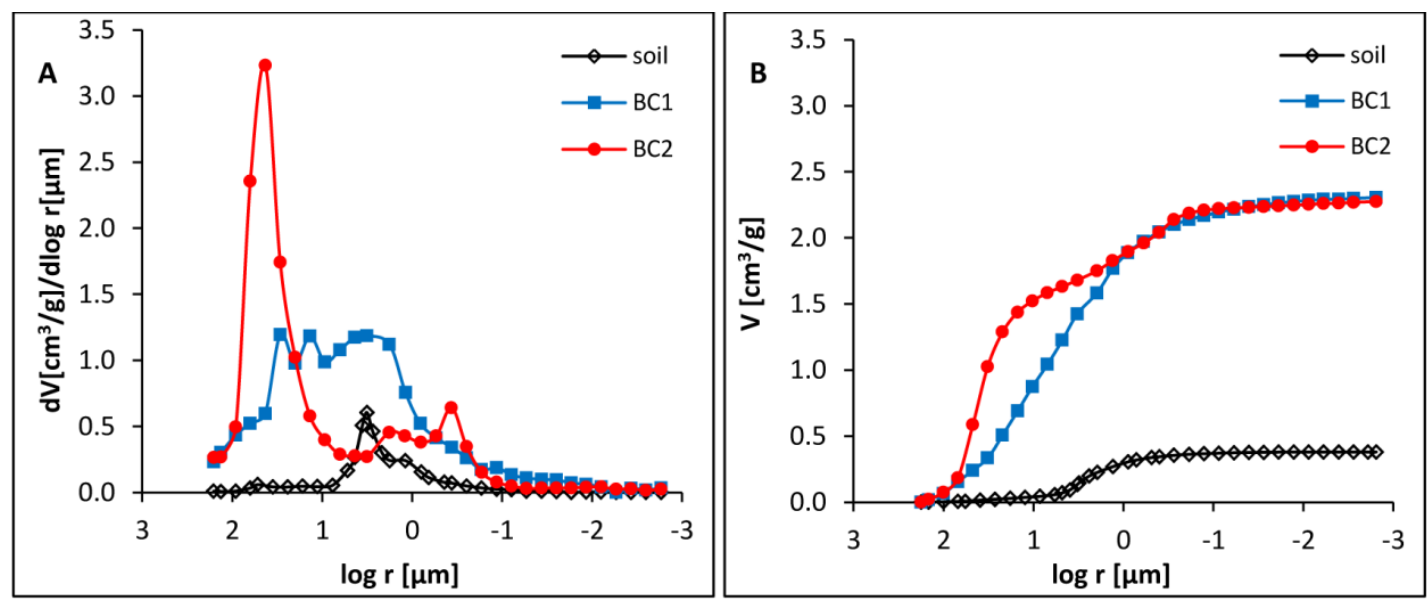

Figure 2. Differential (A) and cumulative (B) curves of pore volume vs. equivalent pore radius of Dystric Cambisol and biochar used for cylinder preparation; the curves were drawn based on the mean value of three measurements.

The results indicate that the soil contained macropores in the pore radius range of $0.186-12.4 \mu \mathrm{m}$ (corresponding with $\log r$ in the range of $-0.73-1.09)$ with a maximum of $3.25 \mu \mathrm{m}(\log r=0.51)$. The pore classification accepted by IUPAC (International Union of Pure and Applied Chemistry) was used throughout the study. According to this classification, micropores are characterized by a diameter below $2 \mathrm{~nm}$, mesopores are characterized by a diameter from $2-50 \mathrm{~nm}$, and macropores are characterized by a diameter above $50 \mathrm{~nm}$. These definitions have served well in mercury porosimetry [41].

Both the wood waste $(\mathrm{BC} 1)$ and sunflower husk (BC2) biochars used in the experiments were alkaline and contained large amounts of organic carbon (Table 1). They were characterized by a higher specific surface area than Dystric Cambisol (Table 2): BC1 had a surface area of $69.92 \mathrm{~m}^{2} / \mathrm{g}, \mathrm{BC} 2$ had a surface area of $80.9 \mathrm{~m}^{2} / \mathrm{g}$, and Dystric Cambisol had a surface area of $15.2 \mathrm{~m}^{2} / \mathrm{g}$. The porosity parameters of the used carbon-rich materials were also higher compared to the soil. The total pore area of $\mathrm{BC} 1$ and $\mathrm{BC} 2$ equaled $22.72 \mathrm{~m}^{2} / \mathrm{g}$ and $19.01 \mathrm{~m}^{2} / \mathrm{g}$, whereas the total porosity was 74.4 and $75.9 \%$, respectively. The curves of pore volume vs. equivalent pore radius of Dystric Cambisol and the biochars are also shown in Figure 2. The curves indicate that the biochars contain macropores of larger sizes than Dystric Cambisol. BC1 contained macropores in the pore radius range of 0.15-176.66 $\mu \mathrm{m}$ (corresponding with $\log r$ in the range of $-0.82-2.25)$ and the maxima at 3.93 and $18.17 \mu \mathrm{m}(\log r=0.59$ and 1.26), whereas BC2 contained macropores in the pore radius range of 6.9-176.57 $\mu \mathrm{m}$ ( $\log \mathrm{r}$ is in the range of $0.84-2.25)$ and the maximum at $47.15 \mu \mathrm{m}(\log r=1.67)$. All of the above properties of the biochars are very desirable during soil remediation. Such material may increase the soil $\mathrm{pH}$ value and, owing to high porosity parameters, improve soil sorption abilities [42,43].

\subsection{Porosity of Dystric Cambisol Cylinders with or without Biochar}

The results of performed porosity measurements of cylinders remolded using unfractionated Dystric Cambisol with and without wood waste and sunflower husk biochars are presented in Figures 3 and 4 .

The results showed that cylinders remolded using unfractionated soil with and without biochars were characterized by different pore size distributions. The cylinders without a carbon-rich additive contained macropores in the pore radius range of $0.04-47.24 \mu \mathrm{m}$ ( $\log \mathrm{r}$ is in the range of $-1.39-1.67$ ) with maxima of 1.58 and $4.77 \mu \mathrm{m}(\log r=0.2$ and 0.68$)$ (Figure 3). Their mean pore radius equaled $0.24 \mu \mathrm{m}$, whereas porosity was $39.8 \%$ (Figure 4 ). Both biochars added to the soil samples significantly 
affected the pore size distribution in the cylinders. There were clear increases in pore volume, total porosity, and total pore area, and these increases were even higher in samples with a large biochar dose (5\%). For example, for wood waste with a $5 \%$ dose of biochar, total pore area in the soil artificial aggregate was higher by $1.31 \mathrm{~m}^{2} / \mathrm{g}$ (compared to artificial aggregate without biochar). Moreover, differential curves of pore volume vs. equivalent pore radius indicated that the cylinders with biochar were characterized by macropores of larger sizes. For BC1 with a 5\% dose of biochar, the pore radius range in the cylinders did not change, but the intensity of the maximum corresponding with larger macropores $(4.77 \mu \mathrm{m}, \log r=0.68)$ was significantly higher. On the other hand, for BC2 with a $5 \%$ dose of biochar, the pore radius range was broader-from 0.059 to $57.41 \mu \mathrm{m}(\log r:-1.23-1.76)$-and the maximum corresponding with larger pores shifted toward the higher value of $5.78 \mu \mathrm{m}(\log r=0.76)$.

Thus, it can be stated that after the addition of biochar, macropores of larger sizes formed in the cylinders. Due to the higher content of large macropores in the sunflower husk biochar, the cylinders with this material also contained macropores of larger sizes (compared to those of the wood waste biochar). This indicated that the biochars obtained from different biomasses affected the porosity of Dystric Cambisol cylinders to varying degrees.
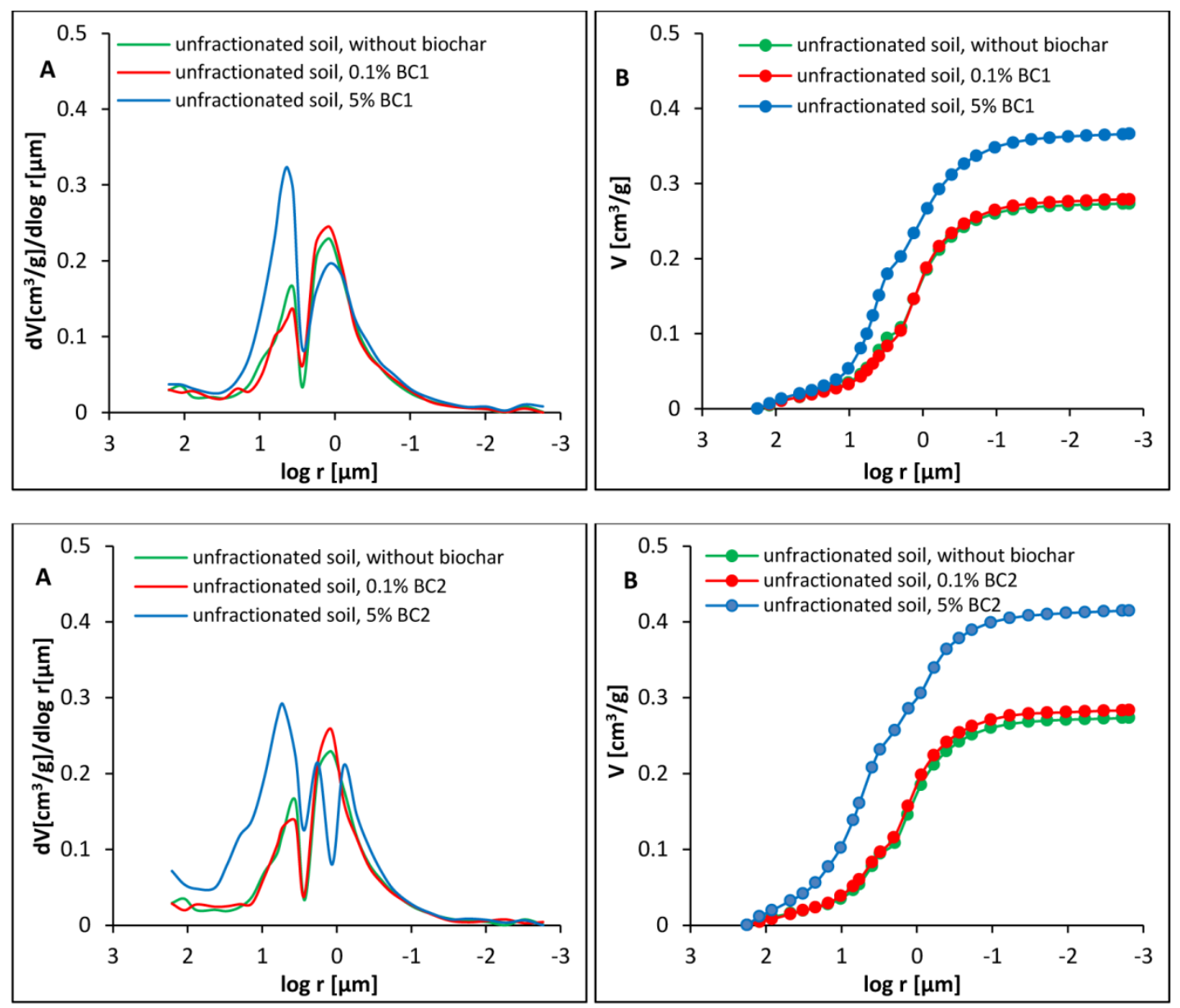

Figure 3. Differential (A) and cumulative (B) curves of pore volume vs. equivalent pore radius of cylinders remolded using unfractionated soil with and without wood waste (BC1) and sunflower husk $(\mathrm{BC} 2)$ biochars; the curves were drawn based on the average value of three measurements. 

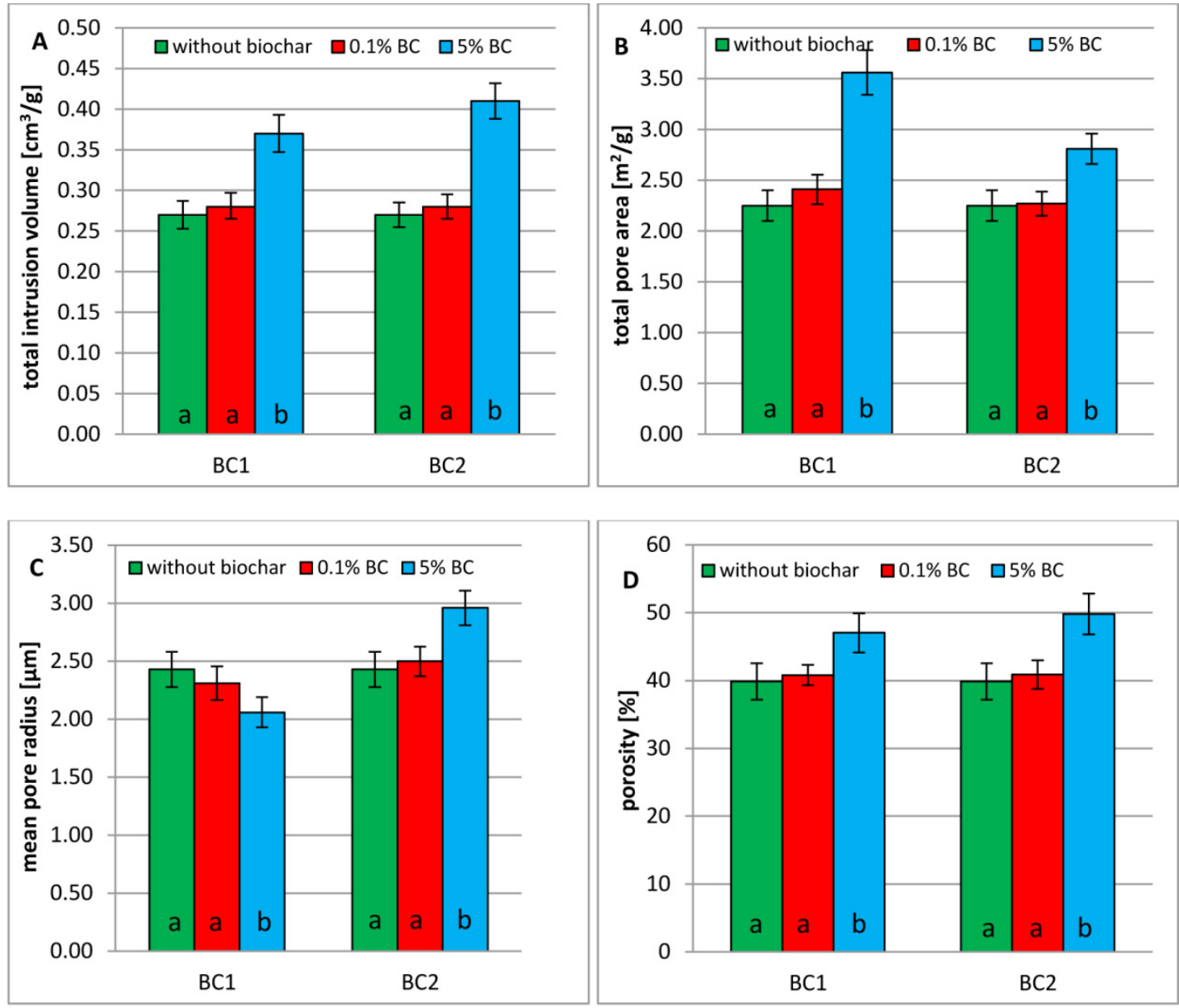

Figure 4. Porosity characteristics of the unfractionated soil cylinders with and without wood waste (BC1) and sunflower husk (BC2) biochars: (A) total intrusion volume, (B) total pore area, (C) average pore radius, (D) porosity; the bars correspond to the standard deviation.

The biochars' impacts on individual Dystric Cambisol fractions was similar. The carbon-rich additive also contributed to an increase in the size of the macropores in the cylinders. The results obtained for both biochars were analogous to those obtained for the unfractionated soil. Therefore, Figures 5-8 show the results only for the sunflower husk biochar (BC2).

Regardless of fraction size, the cylinders with $5 \%$ biochar were characterized by the highest porosity, total pore area, and mean pore radius (Figure 6). Moreover, the samples with a $5 \%$ dose of biochar contained larger macropores than those without biochar. The differential curves of pore volume vs. equivalent pore radius (Figure 5) indicated that the cylinders that formed from Dystric Cambisol fractions without biochar were characterized by macropores in the radius range of 1.3-1.61 $\mu \mathrm{m}$ $(\log r=0.07-0.16)$. In turn, the curves obtained for the cylinders with a $5 \%$ dose of biochar had clear maxima corresponding with $18.17 \mu \mathrm{m}(\log r=1.25)$ and $26.61 \mu \mathrm{m}(\log r=1.42)$ for the $1-0.25 \mathrm{~mm}$ fraction, $6.99 \mu \mathrm{m}(\log r=0.84)$ for the $0.25-0.1 \mathrm{~mm}$ fraction, $6.99 \mu \mathrm{m}(\log r=0.84)$ for the $0.1-0.05 \mathrm{~mm}$ fraction, and $3.94 \mu \mathrm{m}(\log r=0.55)$ for the fraction below $0.05 \mathrm{~mm}$. 

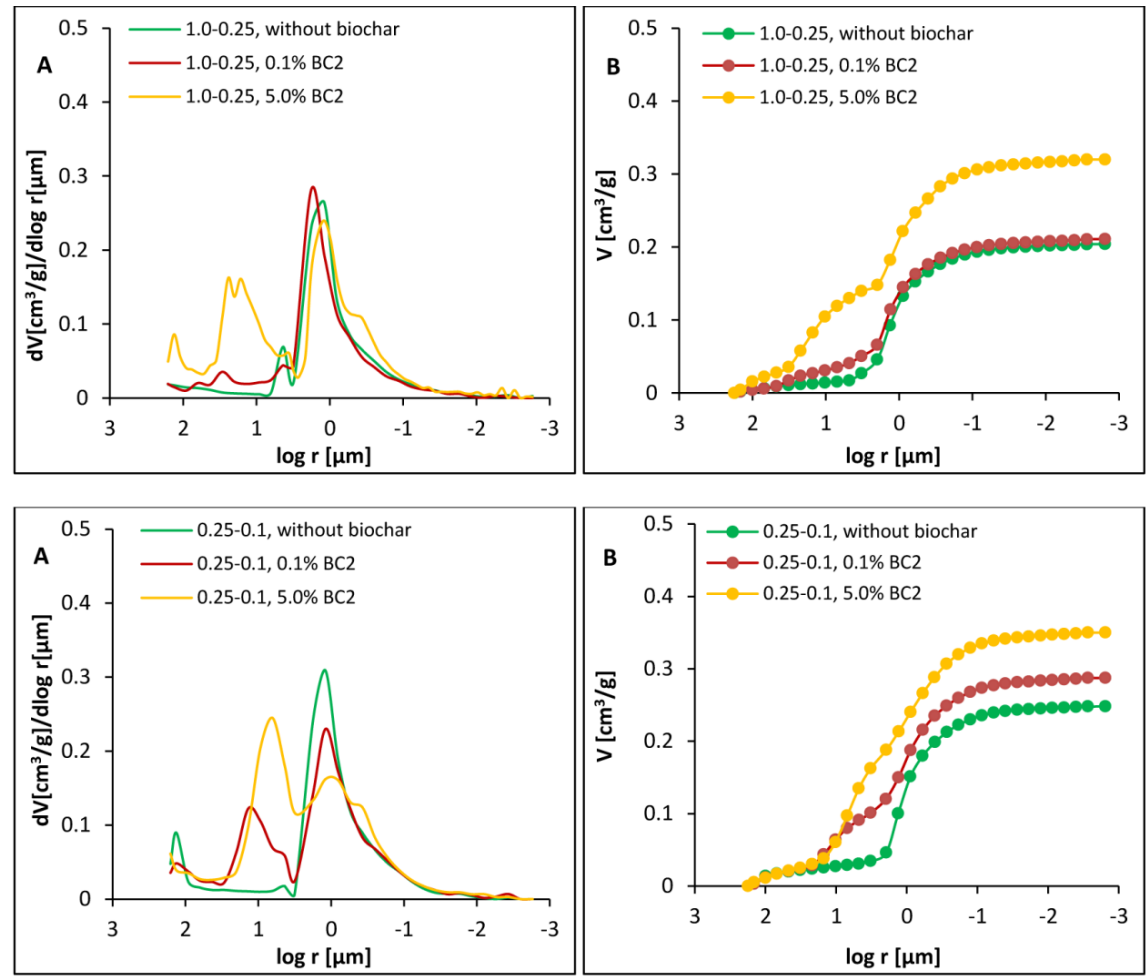

Figure 5. Differential (A) and cumulative (B) curves of pore volume vs. equivalent pore radius of cylinders remolded using selected Dystric Cambisol fractions with and without sunflower husk biochar; the curves were drawn based on the average value of three measurements.
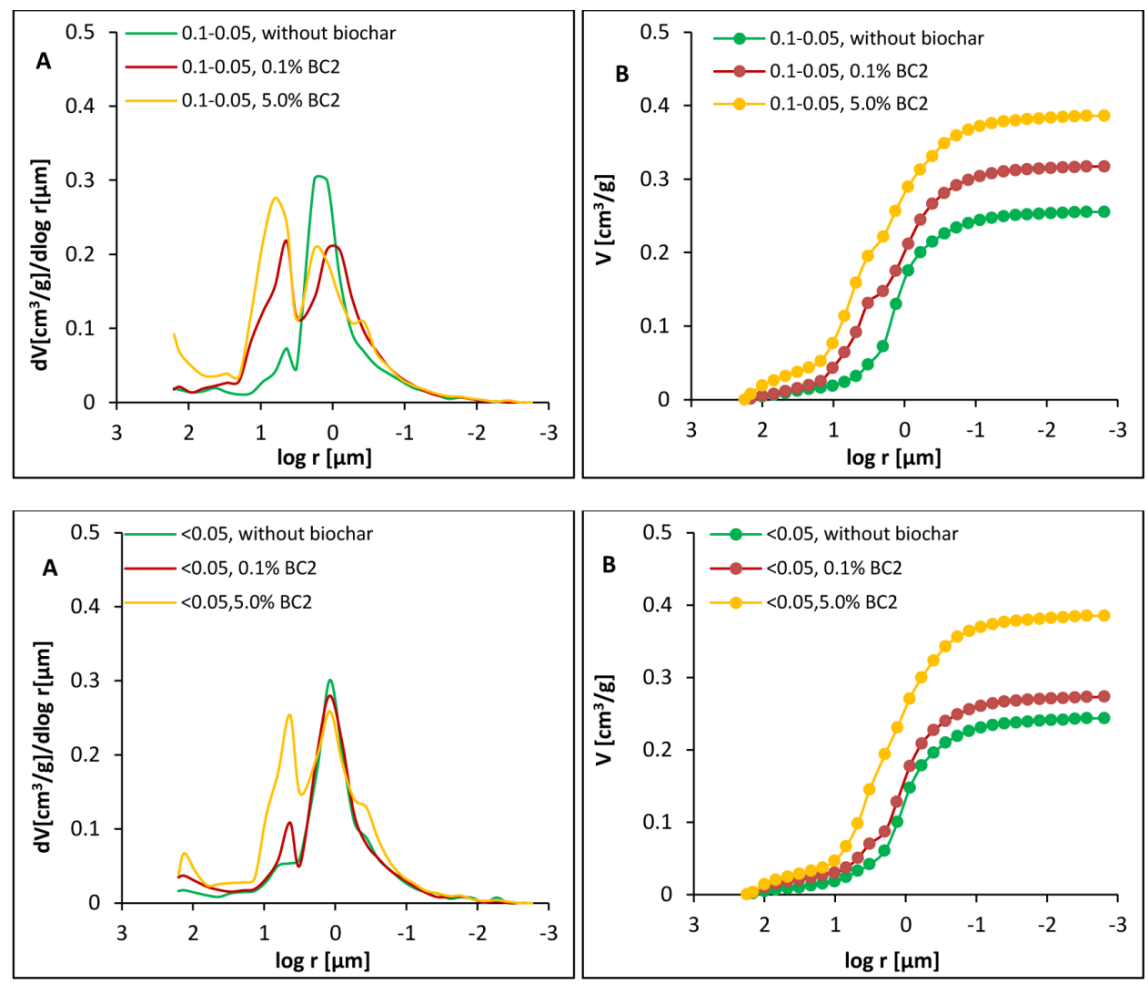

Figure 6. Differential (A) and cumulative (B) curves of pore volume vs. equivalent pore radius of cylinders remolded using selected Dystric Cambisol fractions with and without sunflower husk biochar; the curves were drawn based on the average value of three measurements. 

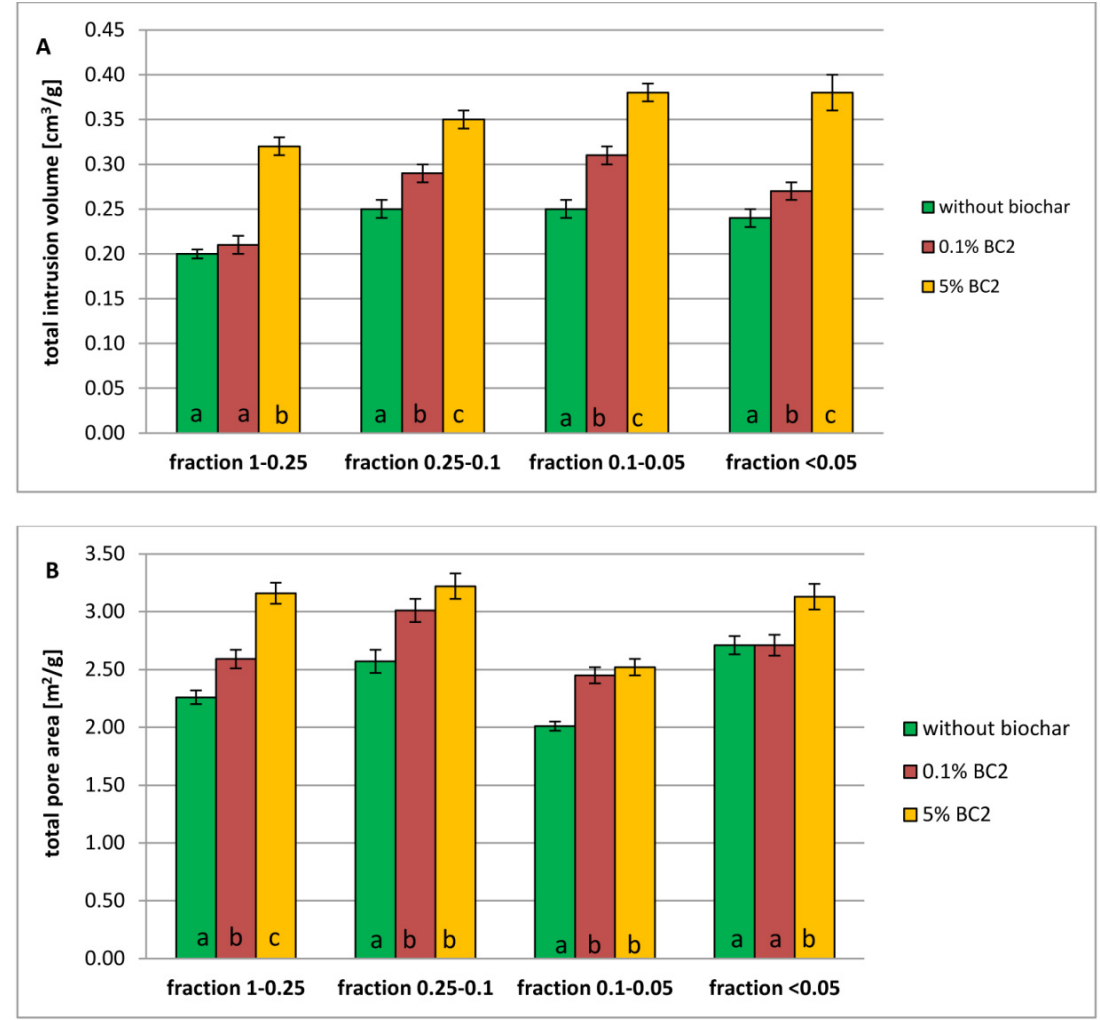

Figure 7. Porosity characteristics of the cylinders remolded using selected Dystric Cambisol fractions with and without sunflower husk biochar (BC2): (A) total intrusion volume, (B) total pore area; the bars correspond to the standard deviation.
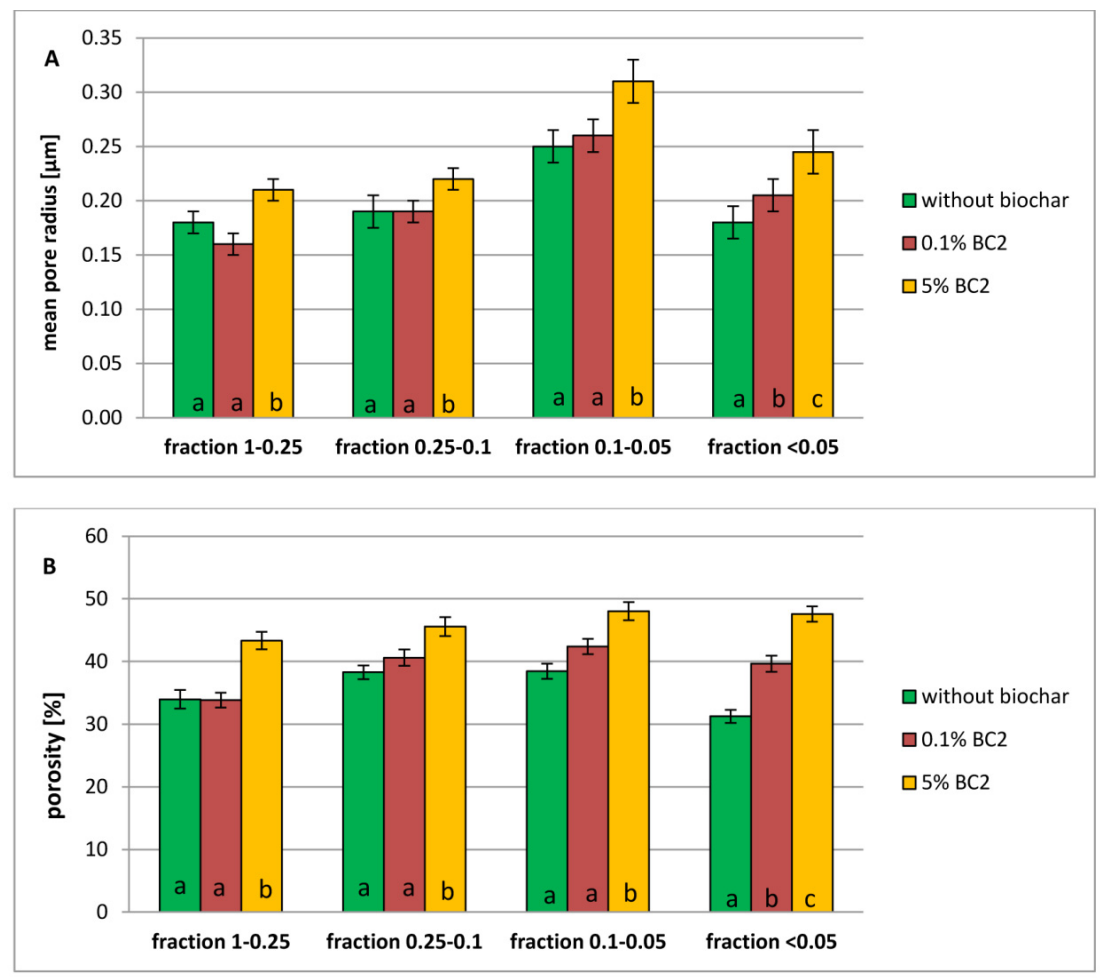

Figure 8. Porosity characteristics of the cylinders remolded using selected Dystric Cambisol fractions with and without sunflower husk biochar (BC2): (A) mean pore radius, (B) porosity; the bars correspond to the standard deviation. 


\subsection{Tensile Strength of Dystric Cambisol Cylinders with or without Biochar}

Aggregate tensile strength is a very important parameter of soil structure stability [30]. It favors the soil's ability to maintain long-term crop productivity by: (1) maintaining gas diffusion, (2) facilitating root penetration, (3) improving water infiltration, and (4) enhancing seedling emergence [25]. The results of the performed tensile strength measurements are presented in Figures 9 and 10.

To compare the impacts of four factors on the tensile strengths of the samples, the $Q$ results were analyzed using a multivariate ANOVA. The interaction plot is presented in Figure 11.

Tensile strength $(Q)$ of unfractionated Dystric Cambisol cylinders without biochar equaled 0.039 of air-dried aggregates and $0.054 \mathrm{MPa}$ of wetted ones. The $Q$ values of air-dried samples formed from selected soil fractions without biochar were in the range of $0.045(0.25-0.01 \mathrm{~mm}$ fraction) to $0.078 \mathrm{MPa}$ (1-0.25 mm fraction), whereas those of wetted ones were in the range of 0.053 (0.1-0.05 $\mathrm{mm}$ fraction) to $0.066 \mathrm{MPa}$ (1-0.25 mm fraction). The highest tensile strength of the $1-0.25 \mathrm{~mm}$ fraction, noted for both air-dried and wetted cylinders, could be related to the large silica content in these samples-the tensile strength of silica is relatively high [44].
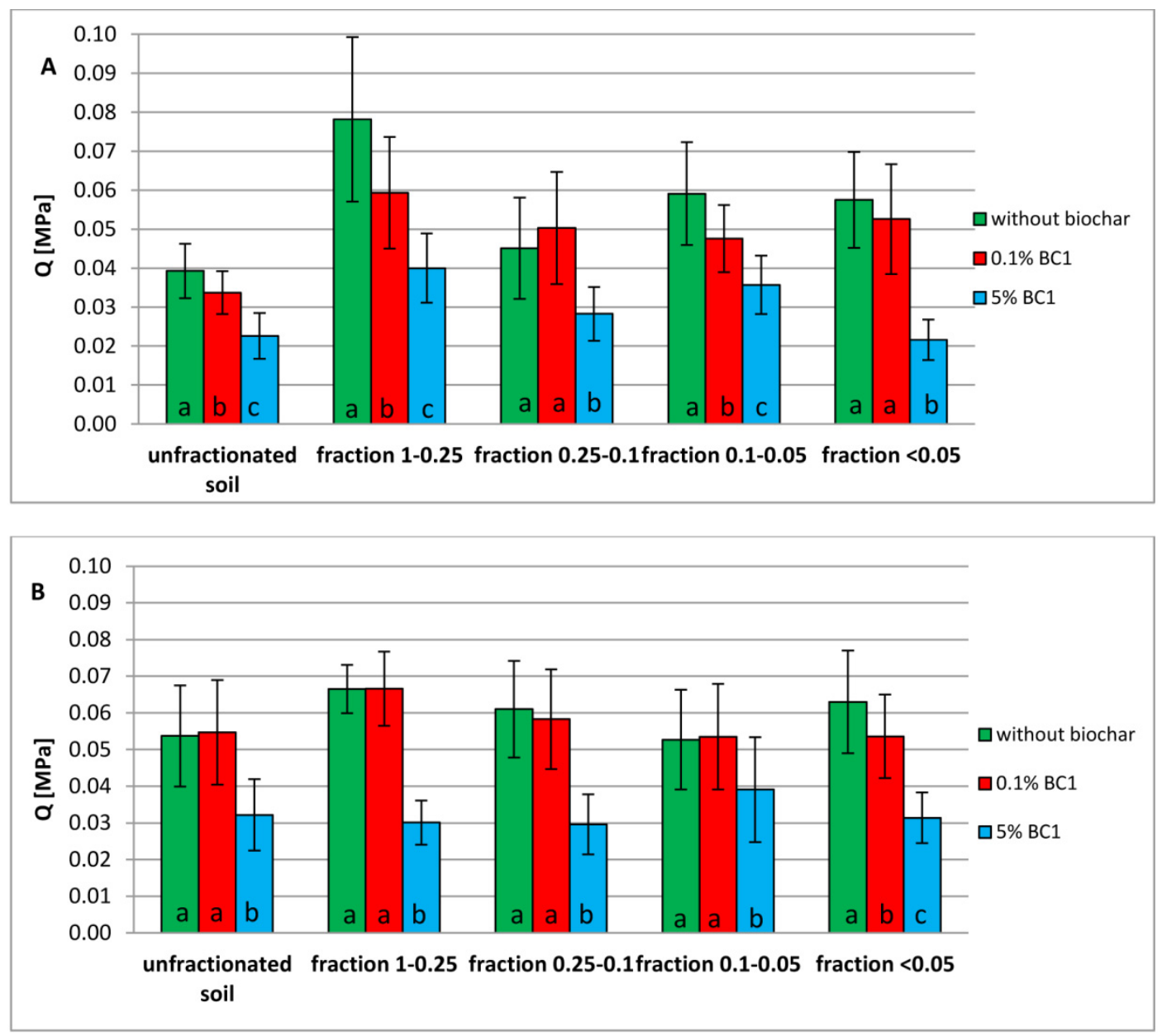

Figure 9. Wood waste biochar (BC1) effect on the tensile strength of air-dried (A) and wetted (B) cylinders formed from the unfractionated soil and its selected fractions; the bars correspond to the standard deviation. 

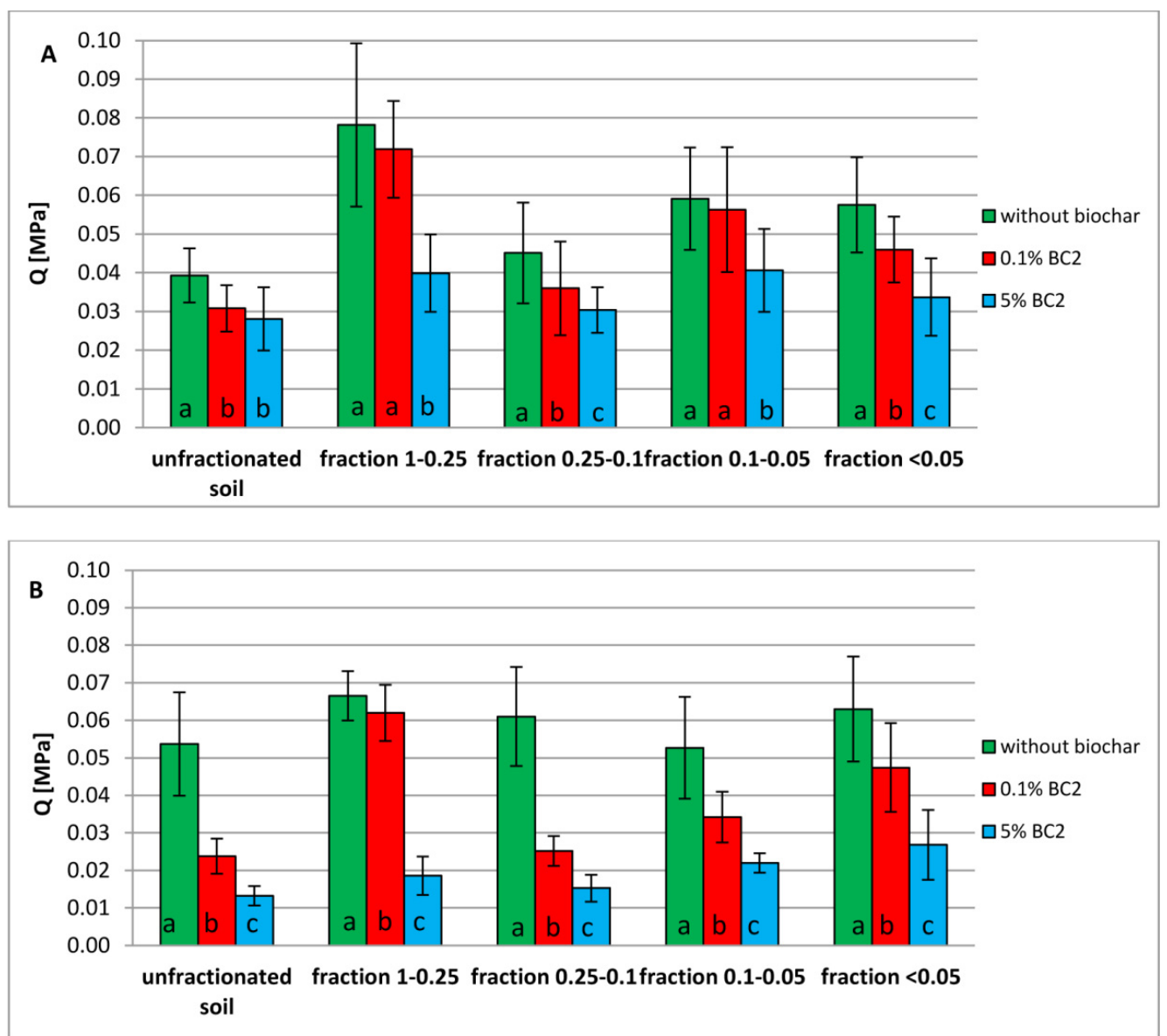

Figure 10. Sunflower husk biochar (BC2) effect on the tensile strength of air-dried (A) and wetted (B) cylinders formed from the unfractionated soil and its selected fractions; the bars correspond to the standard deviation.

The biochar addition decreased the tensile strength of cylinders remolded from unfractionated Dystric Cambisol and its selected fractions. The results were similar for both biochars, but they were dependent on a carbon-rich material dose. In many cases, there were no significant differences between the soil without and with a biochar dose of $0.1 \%$. This phenomenon was noted for air-dried cylinders formed from the fractions of $0.25-0.1 \mathrm{~mm}$ and below $0.05 \mathrm{~mm}$ with $\mathrm{BC} 1$, wetted cylinders of the unfractionated soil and almost all its fractions (except that below $0.05 \mathrm{~mm}$ ) with $\mathrm{BC} 1$, air-dried cylinders of $1-0.25 \mathrm{~mm}$, and $0.01-0.05 \mathrm{~mm}$ fractions with BC2. For the remaining samples with $0.1 \%$ biochar and all samples with $5 \%$ biochar, a significantly lower tensile strength was observed compared to samples without biochar. The largest reduction (by $0.048 \mathrm{MPa}$ ) was observed in the case of the sunflower husks with a $5 \%$ biochar dose for the wetted $1-0.25 \mathrm{~mm}$ fraction. The described reduction in tensile strength was dictated by different pore size distributions in the artificial aggregates with and without biochar. As mentioned above, the mercury porosimetry indicated that the cylinders with biochar contained macropores of larger radii than those without biochar.

It must also be mentioned that the tensile strength of air-dried cylinders was in most cases higher than that of wetted ones. Air-dried artificial aggregates were dried in $105^{\circ} \mathrm{C}$, and as a result, they contained no water in their pores. During drying at high temperature, the dehydration of soil gels and thermal transformation of iron and alumina oxides may occur. Due to thermal modification of iron and aluminosilicates, clay particles may form aggregates of sand size and high hardness [45-47]. Drying of capillary water may also cause the transport of suspended and/or dissolved cementing agents toward inter-particle contacts [48]. 

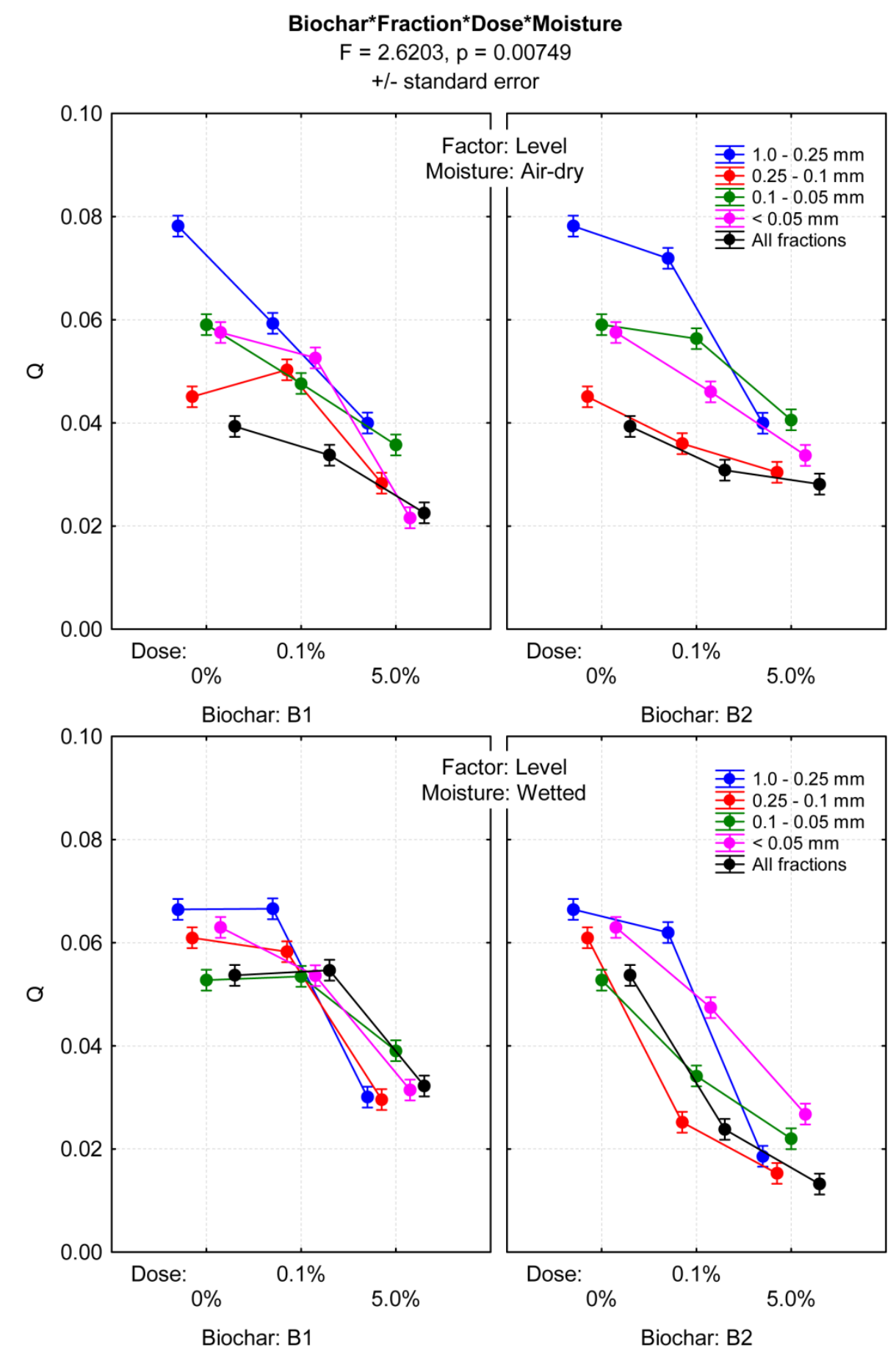

Figure 11. Multivariate ANOVA for four factors (biochar type, biochar dose, soil fraction, and sample moisture) and one variable $Q$ (tensile strength) for air-dried and wetted cylinders.

\section{Conclusions}

The paper focused on the effect of biochar on the tensile strength of artificial aggregates (cylinders) remolded from unfractionated Dystric Cambisol and its selected fractions. The observed changes in cylinder tensile strength were combined with the pore size distribution in the samples. The Dystric Cambisol used for the experiments required remediation due to its low organic carbon content and acidic reaction. The measurements indicated that the cylinders with biochar were characterized by macropores of larger radii than those without the carbon-rich additive. These phenomena were more significant in samples with a higher dose of biochar (5\%). For example, the cylinders remolded from 
unfractionated soil without biochar contained two groups of macropores of $1.58 \mu \mathrm{m}$ and $4.77 \mu \mathrm{m}$. In turn, the cylinders formed using the same material with sunflower husks with a $5 \%$ biochar dose were characterized by macropores of $5.78 \mu \mathrm{m}$. The increase in macropore size in artificial aggregates after the biochar addition contributed to the reduction in tensile strength. The largest reduction (by $0.048 \mathrm{MPa}$ ) was observed in the case of the sunflower husks with a $5 \%$ biochar dose in the wetted $1-0.25 \mathrm{~mm}$ fraction. It must also be emphasized that among all samples, the highest tensile strength of the cylinders was observed for the fraction of the largest particle sizes $(1-0.25 \mathrm{~mm})$; this is probably related to the high silica content in this fraction. Moreover, air-dried cylinders were characterized by a higher tensile strength than wetted ones, which is associated with the dehydration of soil gels and the thermal transformation of iron and alumina oxides during drying.

Author Contributions: Conceptualization, Z.S., K.S.-K.; methodology, Z.S., K.S.-K.; software, K.S.-K., M.T., K.S.; validation, Z.S.; formal analysis, K.S.-K., M.T., A.T.; investigation, K.S.-K., M.T., A.T., M.C., K.S.; resources, Z.S., K.S.-K., A.T.; writing—original draft preparation, K.S.-K., M.C.; writing—review and editing, Z.S., K.S.-K., M.C., A.T., K.S.; visualization, K.S.-K., M.C.; supervision, Z.S.; project administration; Z.S.; funding acquisition, Z.S. All authors have read and agreed to the published version of the manuscript.

Funding: The research was partly performed as a part of the project "Water in soil-satellite monitoring and improving the retention using biochar" no. BIOSTRATEG3/345940/7/NCBR/2017 which was financed by the Polish National Centre for Research and Development in the framework of the "Environment, agriculture and forestry" BIOSTRATEG strategic R\&D program.

Acknowledgments: We would like to thank the directors of the Institute of Agrophysics PAS in Lublin and B. Usowicz for their support.

Conflicts of Interest: The authors declare no conflict of interest.

\section{References}

1. Sarker, T.C.; Incerti, G.; Spaccini, R.; Piccolo, A.; Mazzoleni, S.; Bonanomi, G. Linking organic matter chemistry with soil aggregate stability: Insight from 13C NMR spectroscopy. Soil Biol. Biochem. 2018, 117, 175-184. [CrossRef]

2. Christensen, B.T. Physical fractionation of soil and structural and functional complexity in organic matter turnover. Eur. J. Soil Sci. 2001, 52, 345-353. [CrossRef]

3. Keil, R.G.; Mayer, L.M. Mineral matrices and organic matter. In Treatise on Geochemistry, 2nd ed.; Holland, H.D., Turekian, K.K., Eds.; Elsevier: Oxford, UK, 2014; pp. 337-359.

4. Oades, J.M. The role of biology in the formation, stabilization and degradation of soil structure. Geoderma 1993, 56, 377-400. [CrossRef]

5. Rillig, M.C.; Aguilar-Trigueros, C.A.; Bergmann, J.; Verbruggen, E.; Veresoglou, S.D.; Lehmann, A. Plant root and mycorrhizal fungal traits for understanding soil aggregation. New Phytol. 2015, 205, 1385-1388. [CrossRef] [PubMed]

6. Doerr, S.H.; Shakesby, R.A.; Walsh, R. Soil water repellency: Its causes, characteristics and hydro-geomorphological significance. Earth Sci. Rev. 2000, 51, 33-65. [CrossRef]

7. Beesley, L.; Inneh, O.S.; Norton, G.J.; Moreno-Jiménez, E.; Pardo, T.; Clemente, R.; Dawson, J.J.C. Assessing the influence of compost and biochar amendments on the mobility and toxicity of metals and arsenic in a naturally contaminated mine soil. Environ. Pollut. 2014, 186, 195-202. [CrossRef]

8. Lehmann, J.; Joseph, S. Biochar for environmental management: An introduction. In Biochar for Environmental Management; Lehmann, J., Joseph, S., Eds.; Science and Technology, Earthscan: London, UK, 2009; pp. 1-12.

9. Yang, D.; Yunguo, L.; Shaobo, L.; Xixian, H.; Zhongwu, L.; Xiaofei, T.; Guangming, Z.; Lu, Z. Potential Benefits of Biochar in Agricultural Soils: A Review. Pedosphere 2017, 27, 645-661.

10. Shrestha, G.; Traina, S.J.; Swanston, C.W. Black carbon's properties and role in the environment: A comprehensive review. Sustainability 2010, 2, 294-320. [CrossRef]

11. Glaser, B.; Lehmann, J.; Zech, W. Ameliorating physical and chemical properties of highly weathered soils in the tropics with charcoal-A review. Biol. Fertil. Soils 2002, 35, 219-230. [CrossRef]

12. Jatav, H.S.; Jayant, H.; Kumar, S.; Kumar, V.; Chattopadhyay, A.; Dhawal, S.K.; Singh, Y.V. Role of Biochar: In agriculture sector its implication and perspective. Int. J. Chem. Stud. 2017, 5, 14-18. 
13. Sukaronto; Utomo, W.H.; Kusuma, Z.; Nugroho, W.H. Soil Fertility Status, Nutrient Uptake and Maize (Zea mays L.) Yield Following Biochar and Cattle Manure Application on Sandy Soils of Lombok, Indonesia. J. Trop. Agric. 2011, 49, 47-52.

14. Brandstaka, T.; Helenius, J.; Hovi, J.; Kivela, J.; Koppelmaki, K.; Simojoki, A.; Soinne, H.; Tammeorg, P. Biochar Filter: Use of Biochar in Agriculture as Soil Conditioner. Report for BSAS Commitment; 2010; pp. 1-22, unpublished.

15. Nigussie, A.; Kissi, E.; Misganaw, M.; Ambaw, G. Effect of Biochar Application on Soil Properties and Nutrient Uptake of Lettuces (Lactuca sativa) Grown in Chromium Polluted Soils. Am. Eurasian J. Agric. Environ. Sci. 2012, 12, 369-376.

16. Ding, Y.; Liu, Y.G.; Liu, S.B.; Li, Z.W.; Tan, X.F.; Huang, X.X.; Zeng, G.M.; Zhou, L.; Zheng, B.H. Biochar to improve soil fertility. A review. Agron. Sustain. Dev. 2016, 36, 36. [CrossRef]

17. Cybulak, M.; Sokołowska, Z.; Boguta, P. Impact of biochar on physicochemical properties of Haplic Luvisol soil under different land use: A plot experiment. Agronomy 2019, 9, 531. [CrossRef]

18. Cybulak, M.; Sokołowska, Z.; Boguta, P.; Tomczyk, A. Influence of $\mathrm{pH}$ and grain size on physicochemical properties of biochar and released humic substances. Fuel 2019, 240, 334-338. [CrossRef]

19. Huang, X.X.; Liu, Y.G.; Liu, S.B.; Tan, X.F.; Ding, Y.; Zeng, G.M.; Zhou, Y.Y.; Zhang, M.M.; Wang, S.F.; Zheng, B.H. Effective removal of $\mathrm{Cr}(\mathrm{VI})$ using $\beta$-cyclodextrin-chitosan modified biochars with adsorption/reduction bifunctional roles. RSC Adv. 2016, 6, 223-228.

20. Rajapaksha, A.U.; Chen, S.S.; Tsang, C.W.T.; Zhang, M.; Vithanage, M.; Mandal, S.; Gao, B.; Bolan, N.S.; Ok, Y.S. Engineered/designer biochar for contaminant removal/immobilization from soil and water: Potential and implication of biochar modification. Chemosphere 2016, 148, 276-291. [CrossRef]

21. Wiśniewska, M.; Nosal-Wiercińska, A.; Ostolska, I.; Sternik, D.; Nowicki, P.; Pietrzak, R.; Bazan-Woźniak, A.; Goncharuk, O. Nanostructure of poly(acrylic acid) adsorption layer on the surface of activated carbon obtained from residue after supercritical extraction of hops. Nanoscale Res. Lett. 2017, 12, 2. [CrossRef]

22. Wiśniewska, M.; Nowicki, P.; Nosal-Wiercińska, A.; Pietrzak, R.; Szewczuk-Karpisz, K.; Ostolska, I.; Sternik, D. Adsorption of poly(acrylic acid) on the surface of microporous activated carbon obtained from cherry stones. Colloids Surf. A 2017, 514, 137-145. [CrossRef]

23. Kazmierczak-Razna, J.; Nowicki, P.; Wiśniewska, M.; Nosal-Wiercińska, A.; Pietrzak, R. Thermal and physicochemical properties of phosphorus-containing activated carbons obtained from biomass. J. Taiwan Inst. Chem. Eng. 2017, 80, 1006-1013. [CrossRef]

24. Horel, A.; Barna, G.; Mako, A. Soil physical properties affected by biochar addition at different plant phaenological phases. Part I. Int. Agrophys. 2019, 33, 255-262. [CrossRef]

25. Hartley, W.; Riby, P.; Waterson, J. Effects of three different biochars on aggregate stability, organic carbon mobility and micronutrient bioavailability. J. Environ. Manag. 2016, 181, 770-778. [CrossRef]

26. Kelly, C.N.; Benjamin, J.; Calderon, F.C.; Mikha, M.M.; Rutherford, D.W.; Rostad, C.E. The incorporation of biochar carbon into stable soil aggregates: The role of clay mineralogy and other soil characteristics. Pedosphere 2017, 27, 694-704. [CrossRef]

27. Sun, F.; Lu, S. Biochars improve aggregate stability, water retention and pore-space properties of clayey soil. J. Plant Nutr. Soil Sci. 2014, 177, 26-33. [CrossRef]

28. Ouyang, L.; Wang, F.; Tang, J.; Yu, L.; Zhang, R. Effects of biochar amendment on soil aggregates and hydraulic properties. J. Soil Sci. Plant Nutr. 2013, 13, 991-1002. [CrossRef]

29. Šimanský, V. Effects of biochar and biochar with nitrogen on soil organic matter and soil structure in Haplic Luvisol. Acta Fytotech. Zootech. 2016, 19, 129-138. [CrossRef]

30. Khademalrasoul, A.; Naveed, M.; Heckrath, G.; Kumari, I.; dr Jonge, L.W.; Elsgaard, L.; Vogel, H.-J.; Iversen, B.V. Biochar effects on soil aggregate properties under no-till maize. Soil Sci. 2014, 179, $273-283$. [CrossRef]

31. Ajayi, A.E.; Horn, R. Biochar-induced changes in soil resilience: Effects of soil texture and biochar dosage. Pedosphere 2017, 27, 236-247. [CrossRef]

32. Zhou, H.; Feng, H.; Zhang, Q.; Wang, Q.; Chen, C.; Mooney, S.J.; Peng, X.; Du, Z. Biochar enhances soil hydraulic function but not soil aggregation in a sandy loam. Eur. J. Soil Sci. 2018, 70, 291-300. [CrossRef]

33. Polish Standard PN-Z-19010-1 Soil Quality. Determination of Specific Surface Area of Soils by Water Sorption (BET); ALFA-WERO: Warsaw, Poland, 1997. (In Polish) 
34. Tyurin, I.V. Tyurin's method. In Analytical Methods of Nutrients in Soil; Committee of the Analytical Methods of Nutrients in Soil, Ed.; Japanese Society of Soil Science and Plant Nutrition, Yakendo Co.: Tokyo, Japan, 1980; pp. 120-124.

35. Alten, F.; Wandrowski, B.; Knippenberg, E. Beitrag zur Humusbestimmung. Ergebn. Agrikulturchemie 1935, IV B, 61-69.

36. ASTM D4284-12. Standard Test Method for Determining Pore Volume Distribution of Catalysts and Catalyst Carriers by Mercury Intrusion Porosimetr; ASTM International: West Conshohocken, PA, USA, 1994.

37. Lipiec, J.; Hajnos, M.; Świeboda, R. Estimating effects of compaction on pore size distribution of soil aggregates by mercury porosimeter. Geoderma 2012, 179, 20-27. [CrossRef]

38. Brussaard, L.; van Faassen, H. Effects of compaction on soil biota and soil biological processes. In Soil Compaction in Crop Production; Soane, B.D., van Ouerkerk, C., Eds.; Elsevier: Amsterdam, The Netherlands, 1994; pp. 215-235.

39. Washburn, E.W. The dynamics of capillary flow. Phys. Rev. 1921, 17, 273-283. [CrossRef]

40. Haryanto, Y.; Widyaningrum, A.; Sudibyo, G.H.; Maryoto, A. Mechanical properties of lightweight aggregate concrete reinforced with soda can waste fibre. MATEC Web Conf. 2017, 38, 01021. [CrossRef]

41. Sing, K.S.W. Characterization of porous solids: An introductory survey. Stud. Surf. Sci. Catal. 1991, 62, 1-9.

42. Lei, O.; Zhang, R. Effects of biochars derived from different feedstocks and pyrolysis temperatures on soil physical and hydraulic properties. J. Soil Sediments 2013, 13, 1561-1572. [CrossRef]

43. Hass, A.; Gonzalez, J.M.; Lima, I.; Godwin, H.W.; Halvorson, J.J.; Boyer, D.G. Chicken manure biochar as liming and nutrient source for acid Appalachian soil. J. Environ. Qual. 2012, 41, 1096-1106. [CrossRef]

44. Meleka, N.N.; Bashandy, A.A.; Arab, M.A. Economical reactive powder concrete cast using available materials in North Sinai, Egypt. Arch. Civ. Eng. 2013, LIX 2, 175-195. [CrossRef]

45. Batremieux, R.; Le Borgne, E.; Monnier, G. Evolution de certaines prorietes du sol sous l'influence du chauffage. C. R. Acad. Sci. 1960, 251, 2752-2755.

46. Giovannini, G.; Lucchesi, S.; Giachetti, M. Beneficial and detrimental effects of heating on soil quality. In Fire in Ecosystem Dynamics; Goldammer, J.C., Jenkins, M.J., Eds.; SPB Academic Publishing: Ann Arbor, MI, USA, 1990; pp. 95-102.

47. Arcenegui, V.; Mataix-Solera, J.; Guerro, C.; Zornoza, R.; Mataix-Beneyto, J.; Garcia-Orenes, F. Immediate effects of wildfires on water repellency and aggregate stability in Mediterranean calcareous soils. Catena 2008, 74, 219-226. [CrossRef]

48. Albalasmeh, A.; Ghazzehei, T. Soil aggregate formation: The role of wetting-drying cycles in the genesis of interparticle bonding. Geophys. Res. Abstr. 2013, 15. 